\title{
Urania as a 100-year old magazine, coeval with the IAU
}

\author{
Krzysztof Czart $^{1}$ and Maciej Mikołajewski ${ }^{2}$ \\ ${ }^{1}$ Urania - Postępy Astronomii, \\ Centrum Astronomii UMK, ul. Gagarina 11, 87-100 Torun, Poland \\ email: k.czart@urania.edu.pl \\ ${ }^{2}$ Urania - Postępy Astronomii \\ Centrum Astronomii UMK, ul. Gagarina 11, 87-100 Torun, Poland \\ email: mamiko@umk.pl
}

\begin{abstract}
Urania" is a popular Polish astronomy magazine, one of the oldest in the world among present journals of this type. The first official issue was published in 1922, but the origins of "Urania" are even older, as in 1919 and 1920 there were published a few issues of a predecessor of "Urania" with the same title. So we can say that "Urania" and the IAU are of the same age. The role of "Urania" has been changing during these 100 years, but the magazine has been always a very important entity for the astronomical community in Poland, both professional and amateur. Thousands of pages contain an historical record of astronomy in Poland, as well as the progress of astronomy in the world, including IAU activities.
\end{abstract}

Keywords. magazines, media, communicating astronomy, miscellaneous

\section{Overview of Urania}

Urania - Postępy Astronomii, shorter version: Urania, is a Polish bi-monthly popular science magazine about astronomy and space. It has a circulation of 3000 copies and a large web portal with 50000-100000 users monthly, a Facebook page with about 15000 likes, as well as a Urania TV channel on YouTube. Urania is now and was in history very important for the Polish astronomical community, amateur as well as professional. Its role changed over time with the evolution of media and the internet, but it always was important.

The publishers of Urania are jointly the Polish Astronomical Society - an organization of professional astronomers established in 1923 (www.pta.edu.pl, Polish name: Polskie Towarzystwo Astronomiczne - PTA) and the Polish Society of Amateur Astronomers, an organization of amateur astronomers, established in 1921 with a tradition from 1919 (www.ptma.pl, Polish name: Polskie Towarzystwo Mionikw Astronomii - PTMA).

The history of Urania dates back to 1919. A predecessor of Urania was published in 1919 and 1920 by a group of secondary school students from Warsaw, who establised an interschool astronomy club. The first issue was published in November 1919 with the title Uranja. Sample articles from issues from 1920 are: a possible transneptunian planet, description of various aspects of Einstein's theory, considerations about conditions for potential life on Mars.

The Club of Astronomy Amateurs was reactivated in 1921 as a nationwide organization, the Society of Amateur Astronomers (now: Polish Society of Amateur Astronomers). In 1922 the society published Uranja, keeping the name of previous magazine, but starting numbering from 1. 

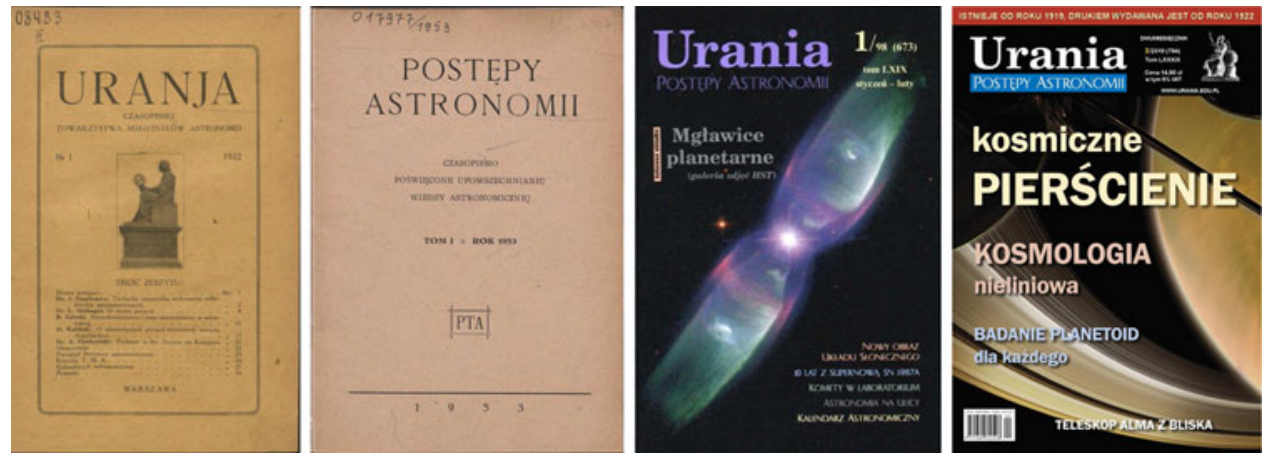

Figure 1. Covers of Urania. From left: first issue of Urania 1/1922, first issue of Postępy Astronomii 1/1953, first issue after merging Urania with Postępy Astronomii 1/1998, nowadays Urania 2/2018.

A large reform of Polish orthography was conducted in 1936. The result of these changes was the transformation of the title from Uranja into Urania. The latter version has been kept until now.

A new magazine Posteppy Astronomii (Advances in Astronomy) was started by the Polish Astronomical Society in 1953. The idea was that Urania would be a magazine for astronomy amateurs, with easier articles, and Postępy Astronomii would be for professional astronomers, astronomy students and advanced astronomy amateus, with more difficult or even scientific articles.

Postȩpy Astronomii changed its formula into a more popular science magazine in 1992. Both publishers decided to merge their titles in 1998 and from monthly Urania and quartarely Postępy Astronomii there was created bi-monthly Urania - Postępy Astronomii, with preservation of numbering of Urania as the older one. Sample covers of Urania are presented in Fig. 1.

The whole archive of Urania was digitized in 2013-2014 and is available for free at the web portal of the magazine www.urania.edu.pl/archiwum, as well as in Google Books and Google Play. Copies are also stored in the Digital Library of Kujavia-Pomerania and in the national archive of digital data. The exception to free access are issues from the last few years, which are still on sale. The Urania archive is a valuable resource for the history of astronomy, both Polish and international. It can also be used, for example, in research on changes in the Polish language and changes in astronomical language.

One may read more about the history of Urania in Włodarczyk (2014) and about activities of Urania in Czart \& Mikołajewski (2014, 2016, 2018).

\section{Story of the first Urania (Uranja)}

The first printed issue of Urania was published in 1922 (at that time the title was typed Uranja). But the magazine had a precedessor from 1919 with the same title. For a long time it was thought that information about these "legendary" issues existed only in the memories of the oldest generation of Polish astronomers from the 20th century, and any older issues did not survive the difficult times of Polish history.

However, an unexpected discovery was made in 2014. The family of Prof. Zbigniew Wasiutynski donated his heritage to the Polish Academy of Sciences. Zbigniew Wasiutynski was an engineer who was building bridges, but his brother was Jeremi Wasiutynski, an astronomer. Materials were examined by Prof. Jarosław 

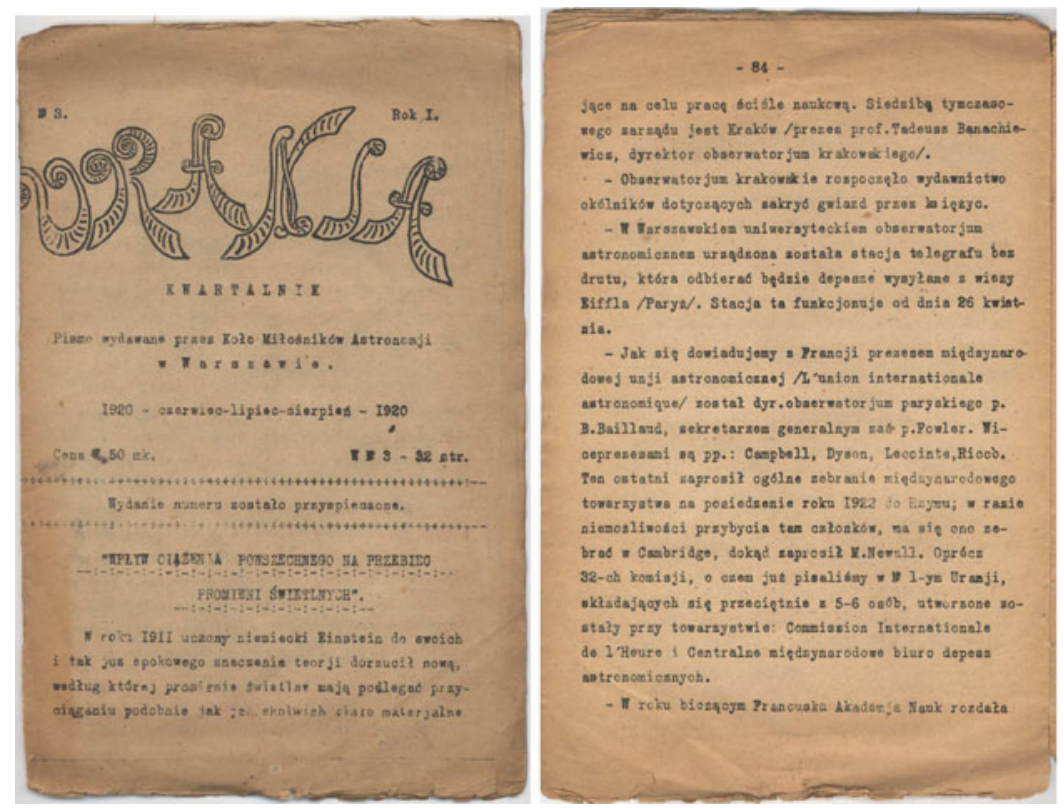

Figure 2. Left: cover of Urania No. 3/1920, right: page 84 with text about IAU.

Włodarczyk - an historian of astronomy - and two issues of the "mythical" Urania were found: 2/1920 and 3/1920. Details are described in Włodarczyk (2014).

\section{Connections between Urania and the IAU}

We may found connections between the magazine Urania and the International Astronomical Union (IAU) since the very beginning of Urania. Here we present a few examples from various years.

In the issue 3/1920 of Uranja at the page 84 in the news reports there is information about the IAU (see Fig. 3). This is presented in Fig. 2, and a translation into English is the following: "As we learn from France, the director of the Paris Observatory, Mr. B. Baillaud, became President of the International Astronomical Union (L'Union Internationale Astronomique), and Mr. Fowler was chosen to be General Secretary. The Vice-presidents are: Campbell, Dyson, Lecointe, Ricco. The last one mentioned invited the international society for a general assembly in Rome in 1922, and in case there is no possibility to come by members, it will be organised in Cambridge, where the invitation was done by M. Newall. Besides 32 commissions, which, as described in Uranja No. 1, consisted of 5-6 people on average, there were created in the society also the Commission Internationale de l'Heure and the Central International Bureau of Astronomical Telegrams."

Uranja No. 1/1919 is not available, but we would like to emphasise a sentence which was written in the above quotation from Uranja No. 3/1920 (what was described in Uranja No. 1), which means that the first issue of Urania also had mentioned about the IAU. We may suppose that it was information about the creation of the IAU.

During the year 1973 a special assembly of the IAU was organized in Poland. This was of course reported and described by Urania. One may read Urania No. 12/1973. Here we present photos from this issue (see Figure 3).

For one of the latest examples we may look into Urania No. 2/2018 where interviews with the global IAU100 coordinator and the International Outreach Coordinator from the Office for Astronomy Outreach are published. 


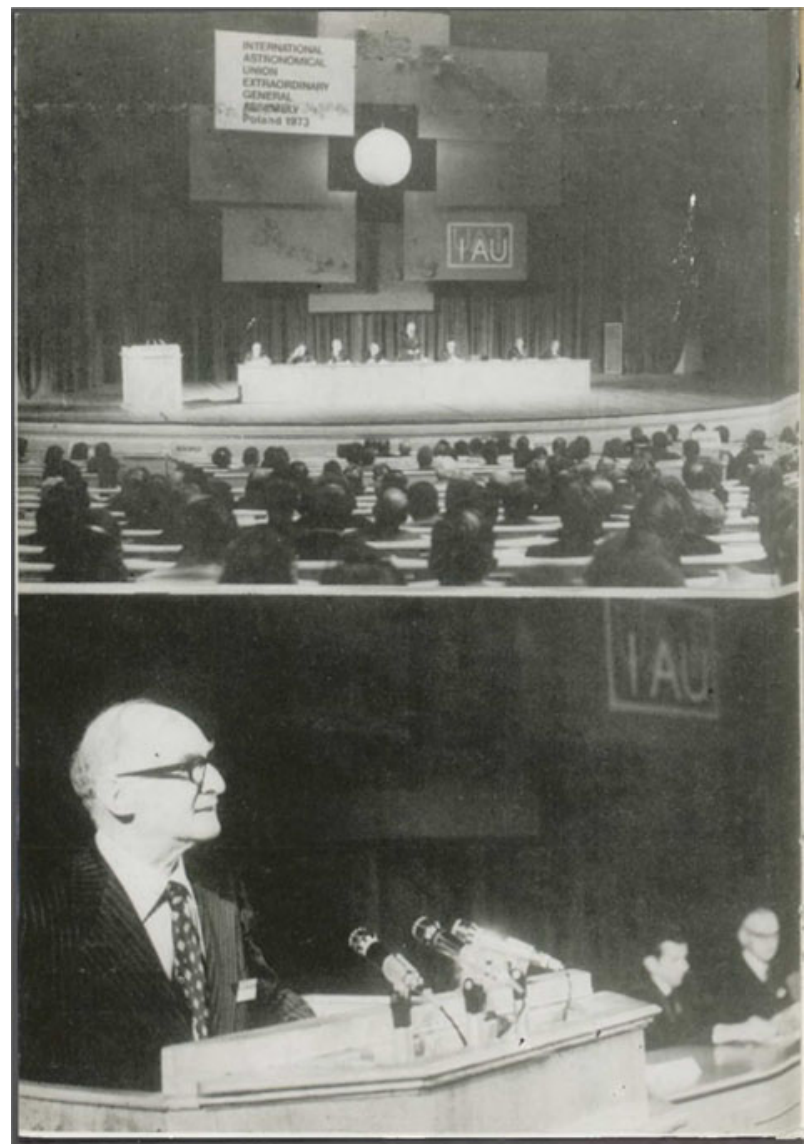

Figure 3. Urania No. 12/1973 - opening ceremony of the special IAU assembly. Top: general view of the conference hall. Bottom: The president of the IAU, prof. L. Goldberg. Photo: CAF.

\section{Discussion}

HeARnshaw: Urania is available free on-line. Has this reduced sales of the print edition?

CzarT: No, it did not reduce sales of the print edition, because current issues are not available for free in digital form. One may buy the digital version of current issues, which are prepared in parallel with the print version, and scanning is not necessary for them. Issues which are still on sale in the print edition are not available for free at this moment, but probably they will be free in future, in a few years perspective.

\section{Acknowledgements}

Digitization of Urania was financed from the funds of the Polish Ministry of Science and Higher Education designated for the dissemination of science.

\section{References}

Czart, K., Mikołajewski, M. 2014, Proceedings of the Polish Astronomical Society, Vol. 1, 107 Czart, K., Mikołajewski, M. 2016, Proceedings of the Polish Astronomical Society, Vol. 3, 261 Czart, K., Mikołajewski, M. 2018, Proceedings of the Polish Astronomical Society, Vol. 7, 393 Włodarczyk, J. 2014, Urania - Postẹpy Astronomii, 5, 8 (in Polish) 